\title{
PERSONAL AND INTERPERSONAL RISK FACTORS IN THE CONSUMPTION OF ILLICIT DRUGS BY MARGINAL ADOLESCENTS AND YOUNG PEOPLE FROM JUVENILE GANGS ${ }^{1}$
}

\author{
Francisco Rafael Guzmán Facundo ${ }^{2}$ \\ Luiz Jorge Pedrão ${ }^{3}$
}

Guzmán Facundo FR, Pedrão LJ. Personal and interpersonal risk factors in the consumption of illicit drugs by marginal adolescents and young people from juvenile gangs. Rev Latino-am Enfermagem 2008 maio-junho; $16(3): 368-74$.

Marginal populations are groups which are known to present higher risks of drug consumption. It is possible to identify adolescents and young people from juvenile gangs that constitute this group. The purpose of this study was to analyze the effect of personal and interpersonal risk factors of drug consumption in 175 marginal adolescents and young people who belong to juvenile gangs in Mexico. Results showed a significant effect of personal factors on drug use, with an estimated variation of $26.1 \%$. The factors that presented the highest rates were: gender, age and mental problems. The interpersonal factors (relationships with friends who have maladaptive behaviors and inappropriate relationships with parents) showed an effect with an estimated variation of $15 \%$. These results will allow for reflection and, in the future, the elaboration of adequate preventive programs aimed at this group of young people.

DESCRIPTORS: adolescent health; street groups; risk groups

\section{FACTORES DE RIESGO PERSONALES E INTERPERSONALES EN EL CONSUMO DROGAS ILÍCITAS EN ADOLESCENTES Y JÓVENES MARGINALES DE BANDAS JUVENILES}

Grupos reconocidos con mayor riesgo para consumir drogas, son los marginales, dentro de estos podemos localizar a los adolescentes y jóvenes de bandas juveniles. El objetivo del estudio fue analizar el efecto de los factores de riesgo personales e interpersonales sobre el consumo de drogas, en 175 adolescentes y jóvenes margínales de bandas juveniles de México. Los resultados mostraron efecto significativo de los factores personales sobre el consumo de drogas, con una varianza explicada del 26.1\%, los factores que mostraron una mayor contribución fueron; el sexo, edad y problemas de salud mental. Los factores interpersonales (relación con amigos con conductas mal adaptadas y relación inapropiada con padres) mostraron un efecto sobre el consumo de drogas, con una varianza explicada del 15\%. Estos resultados posibilitarán la reflexión y en un futuro diseñar programas adecuados dirigidos a la prevención en este grupo de jóvenes.

DESCRIPTORES: salud del adolescente; drogas ilícitas; grupos vulnerables

\section{FATORES DE RISCO PESSOAIS E INTERPESSOAIS NO CONSUMO DE DROGAS ILÍCITAS EM ADOLESCENTES E JOVENS MARGINAIS DE BANDOS JUVENIS}

Grupos reconhecidos com maior risco para o consumo de drogas, são os de populações marginais, e, dentro destas, podemos localizar os adolescentes que pertencem a bandos juvenis. O objetivo do presente estudo foi analisar o efeito dos fatores de risco pessoais e interpessoais sobre o consumo de drogas em 175 adolescentes e jovens marginais de bandos juvenis do México. Os resultados mostraram um efeito significativo dos fatores pessoais com uma variação estimada de $26,1 \%$, sendo que os fatores que mostraram um índice maior foram: sexo, idade e problemas de saúde mental. Os fatores interpessoais: relação com amigos portadores de condutas mal adaptadas e relação e inapropriada com os pais, mostraram efeito com uma variação estimada de $15 \%$. Estes resultados possibilitaram a reflexão e em um futuro desenhar programas adequados direcionados à prevenção neste grupo de jovens.

DESCRITORES: saúde de adolescente; drogas ilícitas; grupos de risco

${ }^{1}$ Paper extracted from Doctoral Dissertation; ${ }^{2}$ Faculty, School of Nursing, Autonomous University of Nuevo Leon, Mexico, e-mail: pako2001@hotmail.com; ${ }^{3}$ Ph.D., Faculty, University of São Paulo at Ribeirão Preto College of Nursing, WHO Collaborating Centre for Nursing Research Development, Brazil, e-mail: lujope@eerp.usp.br 


\section{INTRODUCTION}

Abuse in the consumption of drugs constitutes a public health and social problem in most countries, due to the multiple negative consequences it generates for the emotional and physical development of people ${ }^{(1)}$. Reports from the United Nations show that drug use has increased all over the world in the past few years. At least 200 million people ( $5 \%$ of the world population from 15 to 64 years old) consumed drugs in the last year ${ }^{(1)}$. In Mexico, the consumption of drugs by adolescents and young people is manifested in a distressing way $-3.16 \%$ $(215,634)$ of adolescents between 12 and 17 years old have already consumed drugs once. The drug most often consumed is marijuana, followed by inhalants and cocaine ${ }^{(2)}$.

For some adolescents and young people, the experimental consumption of drugs is a ritual act to go through their individualization stage. In fact, one may say that most of these young people are experimental users. However, for those young people and adolescents who present complex personalities, this may constitute the only alternative they have to cope with personal problems, which makes them more vulnerable to drug addiction. Groups that have been recognized as facing higher risks for drug consumption are the marginal or hidden populations ${ }^{(3)}$. Adolescents and young people who belong to juvenile gangs are part of these groups. Juvenile gangs are recognized as members from the same neighborhood that develop friendship relationships and whose main purposes are: having fun and predominating over rival groups from other neighborhoods, including violent $\operatorname{acts}^{(4)}$.

This kind of adolescents and young people is often excluded from epidemiological surveys on the consumption of drugs. Some national and local publications report an increased number of adolescents and young people who join juvenile gangs in Monterrey, N.L., Mexico. On the other hand, increased levels of violence and social problems related to drug use by these marginal groups has also been observed lately.

Juvenile gangs consist of 7 to 35 members, who are between 10 and 29 years old. They are predominantly male and most of them come from poor neighborhoods, where drug consumption is reportedly one of the main activities ${ }^{(5-7)}$. Therefore, further studies are necessary to explain the risk factors that encourage those adolescents and young people to consume drugs.

Risk factors for using drugs consist of conditions that expose the subjects or make them more vulnerable to start consuming drugs ${ }^{(8)}$. According to national and international literature, personal risk factors have been identified. One of the main factors is gender, with men facing higher risks ${ }^{(9-10)}$; age, i.e., as age increases, so does the probability of consuming some kind of drug( ${ }^{(5,11-12)}$; low education ${ }^{(13)}$; having a job ${ }^{(5,14)}$; and presenting symptoms of mental problems $^{(13,15)}$.

Regarding interpersonal risk factors, literature mentions the facts of having friends who consume drugs or presenting maladaptive behaviors. Studies report that people who have friends who consume drugs are more likely to consume than those who do not have drug-using friends ${ }^{(10,15-16)}$. Inappropriate relationships with parents, such as lack of communication and lack of supervision, are risk factors for adolescents and young people reported by literature ${ }^{(15)}$, as well as having parents who use drugs $^{(10)}$.

In Mexico, the study of the drug consumption phenomenon mainly looks at adolescent students and young people. Despite the advances accomplished, efficient solutions to face the problem have not been found until this moment, and the review of the present literature presented few studies on the problem of drugs in adolescents and young people from juvenile gangs. Thus, this study is highly relevant for nursing professionals in the prevention of drug addiction, analyzing the effects of personal and interpersonal risk factors on drug consumption by marginal adolescents and young people from juvenile gangs. Along with the hypothesis that the interaction of personal risk factors has an effect on drug consumption by adolescents and young people from juvenile gangs, the second hypothesis is that interpersonal risk factors show a positive effect on this consumption.

\section{METHODS}

This study has a descriptive and explanatory design, since it shows the explanatory effect of 
personal and interpersonal risk factors on drug consumption. Study subjects were adolescents and young people, both male and female, from 16 to 29 years old, which belonged to juvenile gangs in the metropolitan area of Monterrey. The sample was analyzed with the $\mathrm{N}$ Query Advisor package, version 4 , for logistic regression with seven variables, potency at .90 and relevance level at .05, for an estimated variation of $20 \%{ }^{(5)}$. The total sample consisted of 175 subjects.

Two instruments and a personal data card were used. The first instrument, called POSIT (Problem-Oriented Screening Instrument for Teenagers), was validated in Mexico ${ }^{(17)}$ and showed acceptable reliability rates $(\alpha=.82)$ for this study. The present study considered only 45 questions, which correspond to: symptoms of mental health problems, inappropriate relationships with parents or guardians, relationships with friends who present maladaptive behaviors and low education. The minimum score for the items was 0 and the maximum 45; the total scale and subscales were converted to rates from 0 to 100 for statistical analysis, indicating that the higher the score, the higher the risk factor. The second instrument used was a History of Drug Use. This instrument addresses the use of illicit drugs some time in life, in the past year, in the past month, as well as the number of days when consumption occurred over the past thirty days.

The project was reviewed and approved by the Committee of Ethics and Research of the Nursing and Obstetrics School at the University of Guanajuato and by the Committee of Ethics and Research of the Nursing School from the Autonomous University of Nuevo León. Subjects were visited at the time and place they meet for class, usually after 8 p.m.. In order to approach the study subjects, urban marginal colonies were visited, where groups of juvenile gangs are observed. The detection of youth groups occurred through key reference sources, such as neighbors. After identifying the colony, the diagnosis of the presence of juvenile gangs was verified, through observations of youth groups and graffiti in the main areas of each colony as indicators of the presence of juvenile gangs, carried out during the day and at night. When the subjects were contacted, the gang members who wanted to participate in the study were required to sign a consent term.

A workgroup was formed in order to collect the study data. It consisted of five nursing professionals who had received training on how to handle the methodology and instruments, as well as how to solve practical problems in the work field. Each researcher was presented to the subjects who accepted to participate. The professionals also tried to isolate them from the rest of the group in order to have more privacy, and explained the study purposes, as well as the relevance of their participation, emphasizing that the data they provided would be handled with absolute confidentiality. Interviews were structured for the face-to-face mode, taking between 15 and 20 minutes each. The researcher read each question and the participant answered, so that they could continue reading the questions, which facilitated their answers.

Data analysis was carried out with the statistical package SPSS version 12, using descriptive statistics based on frequencies and proportions, scoring assessment and central tendency measures. In order to prove both hypotheses, the Logistic Regression Model was applied and results were presented in a chart.

\section{RESULTS}

The study participants' personal data revealed that most of them are male (93.7\%); $82.8 \%$ said they were single; $57.7 \%$ lived with both parents, and $61.7 \%$ said they did not follow any religion. Regarding their occupation, $30.8 \%$ were workers, followed by construction workers (bricklayer [21.1\%]), students $(12.6 \%)$ and unskilled workers $(5.7 \%)$, such as car washers, street vendors and street clowns. A quarter of them said they did not have any occupation $(24.6 \%)$, while $61.7 \%$ said they had a job.

The average age of the study participants was18.11 years, ranging from 16 to 29 years old $(S D=3.32)$. Average time of education was 8.29 years $(S D=1.91)$, varying between two and twelve years. Employed participants' average monthly income was $\$ 3,900$, ranging from $\$ 600$ to $\$ 7,200$ $(\mathrm{SD}=\$ 1368.8)$.

Regarding the consumption of illicit drugs, it is worth mentioning that more than half of the adolescents and young people who belong to a gang said they had already consumed an illicit drug some time in their life (58.9\% [CI 95\%; 51\%-66\%]); 32\% of these young people had consumed only one kind 
of drug, $38 \%$ two kinds and $30 \%$ have consumed three or more kinds of drugs some time in their lives. Table 1 indicates the consumption of illicit drugs. It can be observed that the drug consumed most often is marijuana, followed by inhalants and cocaine.

Table 1 - Consumption of illicit drugs by young people who belong to juvenile gangs

\begin{tabular}{|c|c|c|c|c|c|c|c|c|c|}
\hline \multirow{3}{*}{$\begin{array}{l}\text { Consumption } \\
\text { of drugs }\end{array}$} & \multicolumn{3}{|c|}{ Once in life } & \multicolumn{3}{|c|}{ In the past year } & \multicolumn{3}{|c|}{ In the past month } \\
\hline & \multirow{2}{*}{$\%$} & \multicolumn{2}{|c|}{$\mathrm{C} 195 \%$} & \multirow{2}{*}{$\%$} & \multicolumn{2}{|c|}{$\mathrm{C} 195 \%$} & \multirow{2}{*}{$\%$} & \multicolumn{2}{|c|}{ C195\% } \\
\hline & & $\min$ & $\max$ & & $\min$ & $\max$ & & $\min$ & $\max$ \\
\hline$\overline{\text { Anillicitdrug }}$ & 58.9 & 51 & 66 & 46.3 & 38 & 53 & 40.0 & 32 & 47 \\
\hline Marijuana & 51.0 & 43 & 58 & 36.6 & 29 & 44 & 27.4 & 21 & 34 \\
\hline Cocaine & 29.1 & 22 & 36 & 14.9 & 9 & 20 & 9.7 & 5 & 14 \\
\hline Inhalants & 34.9 & 28 & 42 & 24.0 & 18 & 30 & 20.0 & 14 & 26 \\
\hline
\end{tabular}

Source: HCD

$\mathrm{n}=175$

Table 2 shows results related to the effect of personal risk factors on the consumption of an illicit

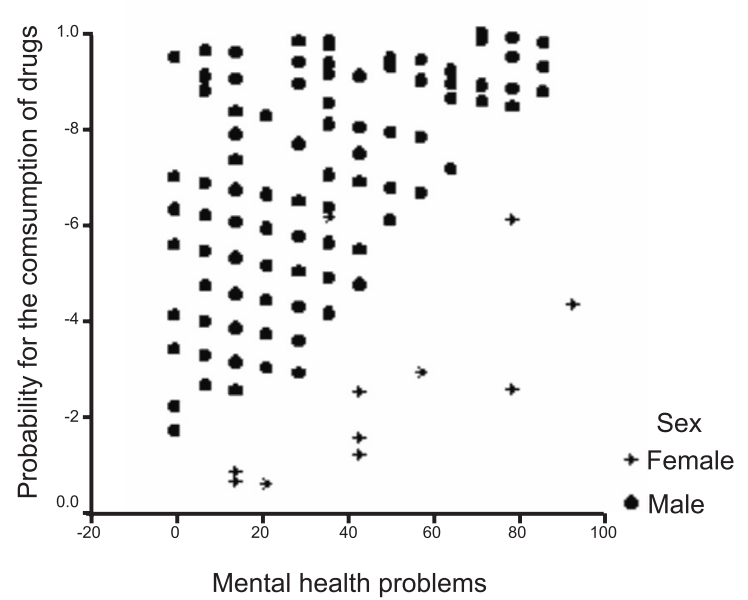

drug. These results indicate that the model was significant $\left(\chi^{2}=52.92, p<.001\right)$ with an estimated variation of $26.1 \%$. By observing the contribution of each variable in the model, it is possible to notice that age, gender and mental health problems showed a significant effect on the model.

Table 2 - Logistic Regression Model for the variables: age, gender, years of education, having a job, mental health problems and low educational towards the consumption of illicit drugs

\begin{tabular}{lccccc}
\hline Source of Variation & B & ES & W & gl & P value \\
\hline Age & .319 & .078 & 16.75 & 1 & .000 \\
Gender & -2.18 & .939 & 5.40 & 1 & .020 \\
Years of education & -.124 & .120 & 1.06 & 1 & .303 \\
Having a job & -.042 & .400 & 0.01 & 1 & .916 \\
Mental health problems & .023 & .011 & 4.88 & 1 & .027 \\
Low education level & .020 & .013 & 2.38 & 1 & .122 \\
Constant & -.3 .03 & 2.14 & 2.38 & 1 & \\
\hline
\end{tabular}

Source: CDP, POSIT and HCD

$\mathrm{n}=175$

$\mathrm{R}^{2}=26.1 \%$

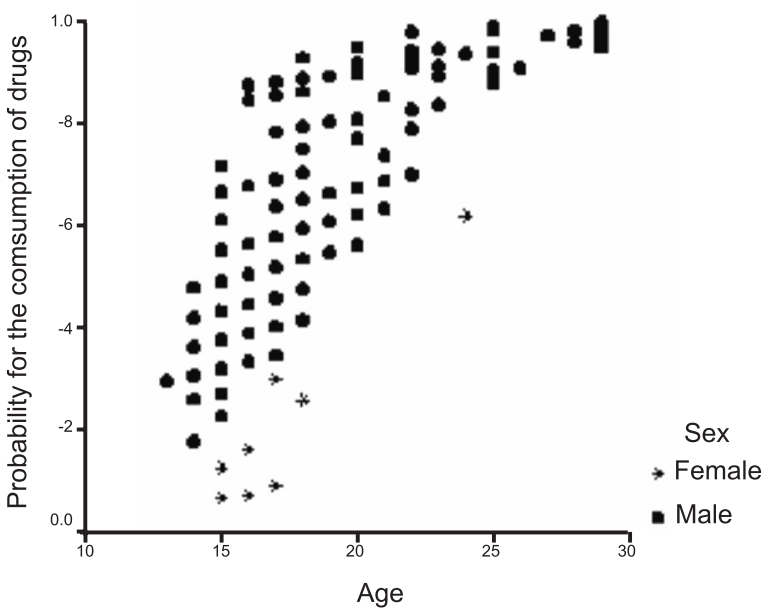

Figure 1 - The effect of mental health problems and age on the consumption of illicit drugs

Figure \#1 shows the effect of age on the consumption of an illicit drug $(\beta=.319, \mathrm{p}<.001)$. It can be observed that, the higher the age, the higher the probability for drug consumption. The same is true for mental health problems, i.e. the higher the level of these problems, the higher the probability for the consumption of illicit drugs $(\beta=.023, p=.027)$. These probabilities are found to be higher for men ( $\beta$ $=-2.18, p<.020)$. Therefore, the results confirm the first hypothesis.

The following data shows the results that prove the second hypothesis. Table 3 presents results for the effect of interpersonal risk factors on the consumption of illicit drugs. Results show that the model was significant $\left(\chi^{2}=28.14 \mathrm{p}<.001\right)$, with an estimated variation of $14.9 \%$.

Table 3 - Logistic Regression Model for the variables: rates of relationship with friends and an inappropriate relationship with parents towards the consumption of an illicit drug

\begin{tabular}{lccccc}
\hline \multicolumn{1}{c}{ Source of Variation } & B & ES & W & gl & $\begin{array}{c}\text { P } \\
\text { value }\end{array}$ \\
\hline Relationship with friends & .026 & .008 & 10.75 & 1 & .001 \\
Inappropriate relationship with parents & .028 & .009 & 8.79 & 1 & .003 \\
Constant & -2.74 & .568 & 21.80 & 1 & \\
\hline
\end{tabular}

Sources: CDP, POSIT and HCD

$\mathrm{n}=175$

$\mathrm{R}^{2}=14.9 \%$ 
Figure \#2 presents the effect of relationships with friends who have maladaptive behaviors on the consumption of illicit drugs $(\beta=.026, p<.001)$. It can be observed that, the higher the rate of relationship with this kind of friends, the higher the probability of

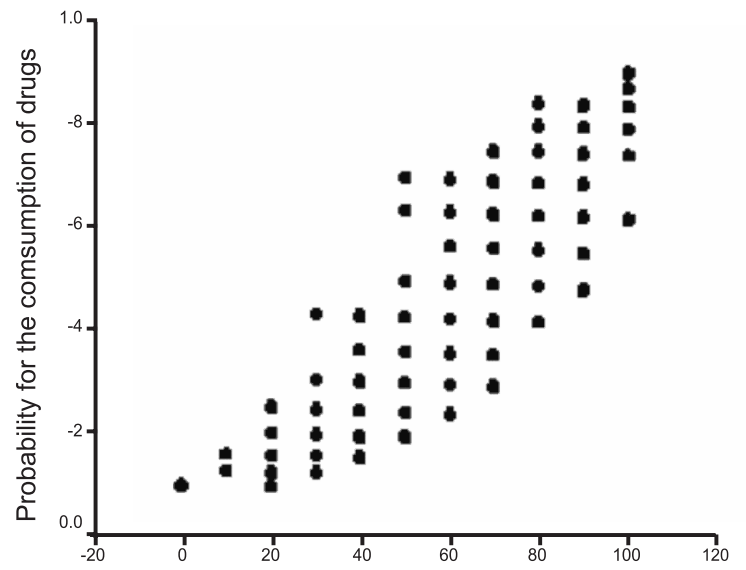

Relationship with friends

consumption of illicit drugs. Likewise, the higher the rate of inappropriate relationship with parents, the higher the probability for consuming illicit drugs $(\beta=.028, p<.003)$. These results confirm the second hypothesis of this study.

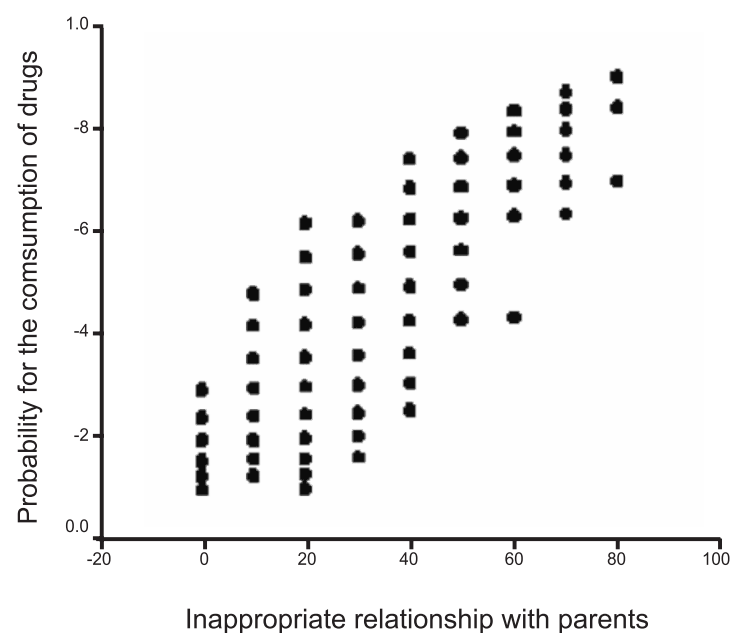

Figure 2 - The effect of a relationship with friends who present maladaptive behaviors and an inappropriate relationship with parents on the consumption of drugs

\section{DISCUSSION}

The present study permittedthe analysis of the predicting effect of some personal and interpersonal risk factors in drug consumption by adolescents and young people who belong to juvenile gangs.

Around $60 \%$ of the study population had already consumed illicit drugs; $32 \%$ of them three or more kinds. Marijuana was found to be the most consumed drug, followed by inhalants and cocaine. These numbers are higher than in a previous study ${ }^{(5)}$, which shows that drug consumption by this population may be increasing. Drug consumption rates were higher than those reported within the general population $^{(2)}$ and within populations of adolescents and young people from school ${ }^{(12)}$ and university ${ }^{(11)}$ groups. Similarly, a study in the United States with young people who belong to gangs or not reported that young people who are members of juvenile gangs presented higher rates of drug consumption ${ }^{(6)}$. Unquestionably, these results show that adolescents and young people who belong to gangs have a higher risk of consuming addictive substances than those who do not.

Thus, the study results support the first hypothesis. Personal risk factors presented an effect on drug consumption, and the factors that most contributed to the model were gender, age and mental health problems. Males presented a higher probability for drug consumption than females. These results are consistent with those reported in similar populations ${ }^{(5-}$ 6) by the National Addiction Survey of $2002^{(2)}$ and studies with adolescents and young people who do not belong to gangs ${ }^{(10)}$. These findings could be explained by the cultural roles of Mexican women. Women tend to be much more aware of their health and avoid risky behaviors, because of the maternity function. This makes them more responsible and careful with themselves than men. In addition, these behaviors are culturally more permissible for men than for women.

The higher the age, the higher the probability for the consumption of drugs; these results agree with Mexican $^{(5)}$ and international ${ }^{(9,14)}$ studies. As adolescents and young people who belong to gangs grow older, their interaction with other social networks probably increases, and they are more likely to be offered these substances. On the other hand, the economic factor for buying drugs plays an important role, since most of the older young people have a job, which allows them to acquire these substances.

The consumption of drugs by minors is alarming, which makes it evident that regulations on this matter actually lack implementation in these 
marginal colonies. Nevertheless, it is known that most drug consumers start before they are 20 years old ${ }^{(2)}$, and these early starts predict higher consumption and addiction levels ${ }^{(13)}$. Consequently, for nursing and healthcare professionals, drug use control effort should aim to prevent the start of consumption.

Another personal factor that was found to be highly predictive for drug consumption was the risk factor of mental health problems, since the higher the rate of mental health problems, the higher the probability for the consumption of drugs. These data were in accordance with other Mexican ${ }^{(5,13)}$ and international $^{(15)}$ studies. The relation between the consumption of drugs and symptoms of depression or anxiety can be an indicator of comorbidity between both conditions. Moreover, this relation may be associated to how these adolescents and young people who belong to juvenile gangs face the emotional problems they experience, as a result of their interactions.

According to the second hypothesis, interpersonal risk factors (relationship with friends who have maladaptive behaviors and inappropriate relationships with parents) showed a positive effect on the consumption of drugs. It was observed that, as relationships with friends who have maladaptive behavior increase, so does the probability for the consumption of drugs. These results agree with previous studies ${ }^{(10,15)}$, and show that the relationship and interaction with friends who are consumers in this group exert a stronger influence since, within the internal dynamics of these groups, the use of drugs is incorporated as the main activity. However, it seems that this is not only the group that looks for the adolescents, but also an element of personal decision, aimed at belonging to the group and, then, trying drugs.

This study found that, the higher the rate of inappropriate relationship with parents, the higher the probability for consuming drugs. These results are compatible with literature, in which higher drug consumption has been observed in adolescents with parents who also use $\operatorname{drugs}^{(9-10)}$. Likewise, it can be observed that lack of communication or having an inappropriate relationship with parents is related to drug consumption ${ }^{(12,15)}$

Drug consumption is one of the activities performed in these groups of adolescents and young people, and it works as a facilitator for social relationships among them. This explains the fact that the group of friends from the gang is the main indicator for drug consumption. This probability increases when the relationship with parents is not appropriate, because the relationship with parents loses its importance for the adolescents and young people who enter gangs. They reinforce the vital value of gang to the detriment of the family, leading to a stronger positive or negative influence of their friends on their behavior.

\section{CONCLUSIONS}

Personal risk factors showed they have an effect on drug consumption, and the factors that most contributed to the model were: gender, age and mental health problems. Interpersonal risk factors, such as relationships with friends who have maladaptive behaviors and inappropriate relationships with parents showed a positive effect on the consumption of drugs.

Nursing, as the science that deals with human responses, is building an appropriate conceptual and technological background for what it has been facing, due to the drugs theme. The results of this study contribute to knowledge in Nursing and other related disciplines, with a view to a better understanding of drug consumption by marginal adolescents and young people from juvenile gangs, adding to the deficient literature that exists about this population. Therefore, the generation and confirmation of knowledge of risk factors for the consumption of drugs by these young people will allow for reflections and, in the future, help design appropriate programs aimed at preventing drug consumption. A significant part of adolescents and young people from juvenile gangs has never consumed drugs, and it is important to explore factors existing in these young people in the future.

In order to define the range and limitations of the present study, it should be mentioned that, as a descriptive correlational study, these results only permit the identification of personal and interpersonal risk factors related to the use of drugs, whose confirmation as risk factors would actually demand the development of cross-section and prospective studies. 


\section{REFERENCES}

1. United Nations Office on Drugs and Crime [UNODC]. World Drug Report 2006; 1. [Acceso Septiembre 2006]. Disponible en: URL: http://www.unodc.org.

2. Consejo Nacional Contra las Adicciones - $(M X)$ [CONADIC] (2003). Encuesta Nacional de Adicciones 2002. Secretaria de Salud, México: [Acceso septiembre 2003]. Disponible en: URL: http://www.salud.gob.mx/unidades/ conadic/.

3. Díaz A, Díaz R, Osornio A, Rascón M. La salud mental en el municipio de Querétaro: un modelo de intervención psiquiátrica en la comunidad. Gac Med Mex 2003; 139(2):101-7.

4. Ruble NM, Turner EL. A systemic analysis of the dynamics and organization of urban street gangs. Am J Fam Ther 2000; 28(2): 117-32.

5. Guzmán FR, Alonso MM, López KS. Factores de riesgo y consumo de drogas en bandas juveniles. Desarrollo Científico Enferm 2006; 14(1): 409-14.

6. Bennett T, Holloway K. Gang Membership, Drugs and Crime in the UK. British J Criminol 2004; 44(3): 305-23.

7. Coughlin B, Venkatesh SA. The urban street gang after 1970. Annual Sociol 2003(29): 41-65.

8. Moncada S. Factores de riesgo y de protección en el consumo de drogas. In: Plan Nacional sobre Drogas. Prevención de las drogodependencia; Análisis y propuestas de actuación. Madrid: Plan Nacional sobre Drogas; 1997. p. 85-101.

9. Nyári TA, Herédi K, Parker L. Adictive behaviour of adolescnets in secondary schools in Hungary. Eur Adict Res 2005; 11: 38-43.

10. Paniagua H, García C, Castellano G, Sarralle R, Redondo C. Consumo de tabaco, alcohol y drogas no legales entre adolescentes y su relación con los hábitos de vida y el entorno. Anales Españolas de Pediatría 2001; 55: 121-8.

11. Rueda LV, Malbergier M, De Andrade V, Guerra A. Fatores associados ao consumo de álcool e drogas entre estudantes universitários. Revista Saúde Pública 2006; 40(2): 280-8. 12. Tavares BF, Béria JU, Silva M. Fatores asociados ao uso de drogas entre adolescentes escolares. Rev. Saúde Pública 2004; 38(6): 787-96.

13. Arrellanes JL, Díaz DB, Wagner F, Pérez V. Factores psicosociales asociados con el abuso y la dependencia de drogas entre adolescentes: Análisis bivariados de un estudio de casos y controles. Salud Mental 2004; 27(3): 54-64.

14. Wu L, Schlenger WE, Galvin DM. The relationship between employment and substance use among students aged 12 to 17. J Adolescent Health 2003; 32: 5-15.

15. Vitaro F, Brendgen M, Ladouceur R, Tremblay RE. Gambling, delinquency, and drug use during adolescence: mutual Influences and commun risk factor. Journal of Gambling Studies 2001; 17(3): 171-90.
16. Latimer W, Floyd LJ, Kariis T, Novotna G, Exnerova P, O'Brien M. Peer and sibling substance use: predictors of substance use among adolescents in Mexico. Rev Panam Salud Publica 2004;15(4):225-32.

17. Mariño MC, González FC, Andrade P, Medina ME. Validación de un cuestionario para detectar adolescentes con problemas por el uso de drogas. Salud Mental (México DF.) $1998 ; 21(2): 27-39$. 